\title{
Immune status is more affected by age than by carotenoid depletion-repletion in healthy human subjects
}

\author{
Marie-Chantal Farges ${ }^{1}$, Régine Minet-Quinard ${ }^{1}$, Stéphane Walrand ${ }^{1}$, Emilie Thivat $^{1}$, Josep Ribalta ${ }^{2}$, \\ Brigitte Winklhofer-Roob ${ }^{3}$, Edmond Rock ${ }^{4}$ and Marie-Paule Vasson ${ }^{1,5_{*}}$ \\ ${ }^{1}$ Clermont Université, Université d'Auvergne, EA 4233, LB2MN, CRNH Auvergne, BP 10448, F-63000 Clermont-Ferrand, \\ France \\ ${ }^{2}$ Universitat Rovira $i$ Virgili, Unitat de Recerca de Lipids i Arteriosclerosi, Reus, Spain \\ ${ }^{3}$ Human Nutrition and Metabolism Research and Training Center (HNMRC), Institute of Molecular Biosciences, \\ Karl-Franzens University, Institute of Molecular Biology, Biochemistry and Microbiology, Graz, Austria \\ ${ }^{4}$ INRA, Unité des Maladies Métaboliques et des Micronutriments (UMMM), CRNH Auvergne, F-63122 Saint-Genès- \\ Champanelle, France \\ ${ }^{5}$ Centre Jean Perrin, Service de Nutrition, F-63000 Clermont-Ferrand, France
}

(Submitted 4 July 2011 - Final revision received 10 January 2012 - Accepted 11 January 2012 - First published online 8 March 2012)

\begin{abstract}
Prospective studies have indicated an age-related impairment of the immune response. Carotenoids have been hypothesised to enhance immune cell function. The aim of the present study was to describe the age-related effects and the impact of in vivo dietary carotenoid depletion and repletion on specific and non-specific immunity. A total of ninety-eight healthy male subjects (aged 20-75 years) received a carotenoid-depleted diet for 3 weeks and were then supplemented daily for 5 weeks with $30 \mathrm{mg} \beta$-carotene, $15 \mathrm{mg}$ lycopene and $9 \mathrm{mg}$ lutein. Blood samples were collected at study entry, after depletion and supplementation, and biomarkers of immune status were determined. We found that serum IgA levels were positively correlated with ageing. Lymphocyte phenotyping indicated an increase with age in the memory T-helper cell subpopulation $\left(\mathrm{CD}^{+} \mathrm{CD} 45 \mathrm{RO}^{+}\right)$concomitantly with a decrease in naive T-helper cells $\left(\mathrm{CD} 4{ }^{+} \mathrm{CD} 45 \mathrm{RA}{ }^{+}\right)$. A significant increase in the natural killer cells subpopulation and a small decrease in B lymphocytes were also observed, especially for the oldest volunteers. From ex vivo cell function exploration, a positive correlation was observed between age and IL-2 production of phytohaemagglutinin-stimulated lymphocytes. Neutrophils' bactericidal activity was significantly impaired with age (from 50 years) and was modulated by carotenoid status. An age effect was found on neutrophils' spontaneous migration but not on directed migration. Immune response in healthy human subjects is mostly affected by age rather than by dietary carotenoid depletion and repletion. Even in carefully selected healthy volunteers, some age-related immune changes occur predominantly from 50 years onwards. This immunosenescence could generate a loss in the immune system adjustment capacity.
\end{abstract}

Key words: $\beta$-Carotene: Dietary depletion and repletion: Delayed-type hypersensitivity: Phagocytosis: Chemotaxis: Interleukins: Immunoglobulins

In recent years, carotenoids have received a tremendous amount of attention as potential anti-cancer and anti-ageing compounds ${ }^{(1,2)}$ and many epidemiological studies have found a relationship between high carotenoid status and a low incidence of age-related diseases ${ }^{(3,4)}$. Moreover, since the immune system plays a key role in cancer prevention, it has been suggested that carotenoid-rich food intake should be increased because of their antioxidant properties ${ }^{(5)}$, and that $\beta$-carotene may enhance immune cell function. While $\beta$-carotene depletion has been rarely studied $^{(6,7)}$, several human trials have examined the effects of $\beta$-carotene supplementation on immune functions by measuring changes in the number of lymphocyte subpopulations and on the expression of cell activation markers ${ }^{(8,9)}$. However, because of the large variation in dietary intakes of $\beta$-carotene and in the duration of supplementation, these works have led to inconsistent results. For example, clinical data have shown that supplementation with $\beta$-carotene stimulates the immune response in healthy adults ${ }^{(8-10)}$ and in the elderly ${ }^{(11)}$.

Abbreviations: AU, arbitrary units; DM, directed migration; DTH, delayed-type hypersensitivity; CI, chemotaxis index; NK, natural killer; PHA, phytohaemagglutinin; PMA, phorbol myristate acetate; PMN, polymorphonuclear neutrophils; ROS, reactive oxygen species; sIL-2R, soluble IL-2 receptor; SM, spontaneous migration; T0, baseline; T1, carotenoid depleted; T2, carotenoid supplemented.

*Corresponding author: Professor M.-P. Vasson, fax +334731780 38, email m-paule.vasson@u-clermont1.fr 
In contrast, other authors ${ }^{(6,12-15)}$ have reported that $\beta$-carotene supplementation had no effect on immune function. In the healthy elderly, no significant difference was found on delayed-type hypersensitivity (DTH), lymphocyte proliferation, IL-2 and $\mathrm{PGE}_{2}$ production, lymphocyte subsets or number of natural killer (NK) cells, either after short-term (3 weeks) or long-term (12 years) supplementation with $90 \mathrm{mg} /$ $\mathrm{d}$ or $50 \mathrm{mg} \beta$-carotene on alternate days, respectively ${ }^{(16)}$. However, $\beta$-carotene supplementation seems to be more effective in enhancing natural immunity (NK cell activity) than T cell-mediated immunity ${ }^{(17-19)}$.

We have previously found that the response of lymphocyte subpopulations to nutritional modifications was significantly affected by age ${ }^{(20)}$. While age-related changes in the immune system have been the subject of investigation for some decades, the ageing effect by itself (with no disease-related or pharmacological interference) on immunological adaptation to carotenoid status changes has never been reported.

The present study aimed to investigate, on healthy male subjects aged between 20 and 75 years, the carotenoids' biological actions on immune status, i.e. on both specific and non-specific immunity, as a function of the age of the subjects. For this purpose, the volunteers received a 3-week diet depleted in carotenoids by a self-controlled vegetable intake, followed by 5 weeks of their usual diet supplemented with $\beta$-carotene as well as lycopene and lutein, two other major dietary carotenoids which have become a major focus in carotenoid research $^{(21-24)}$.

\section{Subjects and methods}

\section{Characteristics of the subjects}

A total of ninety-eight healthy French male volunteers (46.7 (SEM 1.5 ) years) were enrolled from the French volunteer population recruited according to the SENIEUR protocol ${ }^{(25)}$ for the European VITAGE project examining fat-soluble vitamin status and functions during healthy ageing (FP5-RTD, QLK1-CT-9900830). The volunteers were classified into six different age groups: $20-29$ years ( $n$ 19); 30-39 years ( $n$ 17); 40-49 years ( $n$ 18); 50-59 years ( $n$ 18); 60-69 years ( $n$ 19); 70-75 years $(n 7)$. None of the volunteers was suffering from any relevant acute or chronic disease (including diabetes, cancer, cardiac insufficiency, neurological diseases, inflammatory diseases and chronic diseases of the liver, lung or thyroid, non-stable hypertension, dementia, and infectious diseases known to affect the immune system, such as HIV and hepatitis C), had any signs of infection or inflammation or was taking any drugs known to affect the immune system (anti-inflammatory drugs, hormones, analgesics and recent vaccination) or had any special diets or dietary supplements in the past 3 months. The study was conducted according to the guidelines laid down in the Declaration of Helsinki and all procedures involving human subjects were approved by the local Ethics Committee for human clinical research (Gabriel Montpied Hosptital and Auvergne Human Nutrition Research Center, registration number: AU342). Written informed consent was obtained from all subjects before their inclusion in the study.

\section{Experimental design}

All subjects were on a carotenoid-depleted diet for 3 weeks through decreased usual intakes of fruits and vegetables. In order to limit carotenoid intake to $25 \%$ of the usual intakes, a nutritional training was organised to explain to the volunteers how to compose their meals to have low intakes of fruits and vegetables containing carotenoids. Together with specific recommendations to avoid some of the carotenoid-rich food, they were asked to fill in a food-frequency daily questionnaire (food consumption record) on five consecutive days. In addition, we made sure that depletion was identical whatever the age of the volunteer. We then obtained a good compliance regarding the dietary recommendations. The daily intake of energy and macronutrients was as follows: energy 10890 (SEM 261) kJ (2600 (SEM 618) kcal); proteins 106.1 (SEM 3.6) g; carbohydrates $292 \cdot 3$ (SEM 8.2) g; lipids 104.3 (SEm 3.3) g. The daily intake of micronutrients was as follows: vitamin A 589 (SEM 68) $\mu \mathrm{g}$; vitamin C 107 (SEM 8) $\mathrm{mg}$; vitamin E 10.8 (SEM 0.5) $\mathrm{mg} ; \beta$-carotene 2.99 (SEM 0.26) mg; lycopene 2.49 (SEM 0.24) mg; lutein + zeaxanthine 1.34 (sEM 0.13) mg; $\beta$-cryptoxanthine 0.16 (sEm 0.03) mg. Afterwards, participants started the 5 -week repletion period taking three capsules/d containing $30 \mathrm{mg} / \mathrm{d} \beta$-carotene, $15 \mathrm{mg} / \mathrm{d}$ lycopene and $9 \mathrm{mg} / \mathrm{d}$ lutein (corresponding to a total of $54 \mathrm{mg} / \mathrm{d}$ all-trans carotenoids), together with the diet usually consumed before the study. These amounts of carotenoids were determined from previous large carotenoid supplementation studies ${ }^{(26)}$ At the end of each experimental period, compliance of the volunteers was evaluated by an interview with a dietitian. Blood samples were collected into vacutainer tubes containing EDTA (BD Biosciences) at study entry $(12 \mathrm{ml})$ and after the carotenoid depletion $(12 \mathrm{ml})$ and repletion $(6 \mathrm{ml})$ periods. Plasma was rapidly frozen at $-80^{\circ} \mathrm{C}$ until analysis and fresh cells were immediately used for ex vivo experiments.

\section{Plasma carotenoid analysis}

Extraction of carotenoids was performed from plasma samples using ethanol containing echinenone $(0 \cdot 2 \mu \mathrm{g} / \mathrm{ml})$ as an external standard of hexane. After desiccation, the extract was redissolved in the mobile phase (acetonitrile-dichloromethane $(1: 1, \mathrm{v} / \mathrm{v})$; Fisher Scientific). Analysis by reversed-phase HPLC was performed according to a method described previously ${ }^{(27)}$. Plasma carotenoid concentrations $(\mu \mathrm{mol} / \mathrm{l})$ were calculated using their respective standards (Hoffmann-La Roche) in the all-trans form for $\beta$-carotene and lutein, and in both cis and all-trans forms for lycopene. A photodiode array detector supported by the Millemium 32 Chromatography Manager computing system (Waters) was used to confirm the spectrum identity of the carotenoids. Furthermore, the carotenoid concentrations in the sample were corrected by the recovery of the external standard echinenone (Sigma-Aldrich). The recovery rates were between 80 and $100 \%$. The CV was always lower than $10 \%$.

\section{Determination of serum biomarkers of immune status}

IgG, IgA, IgM and complement fraction (C3, C4) concentrations were quantified by immunonephelometry (Array 
Protein System; Beckman-Coulter), using human antibodies (Beckman-Coulter). Values are expressed as g/l. Soluble IL-2 receptor (sIL-2R) concentration ( $\mathrm{pmol} / \mathrm{l})$ was assayed by ELISA (Immunotech SAS).

\section{Determination of delayed-type hypersensitivity}

To determine the DTH skin response, we used the Multitest $\mathrm{CMI}^{\circledR}$ skin applicator (Pasteur-BioMérieux) against seven antigens (tetanus, diphtheria, Streptococcus (C group), tuberculin, Candida albicans, trichophyton and Proteus mirabilis) and a glycerine negative control. Multitest ${ }^{\circledR}$ was applied on the arm skin for at least $5 \mathrm{~s}$. The skin tests were read at $48 \mathrm{~h}$ after application by measuring two diameters expressed in $\mathrm{mm}$ using a gradual scale. Induration of $2 \mathrm{~mm}$ or more in diameter was considered to be positive. The cumulative score was calculated by summing the induration diameter values of all positive reactions.

\section{Determination of blood leucocyte phenotypes}

Lymphocyte subpopulations were measured by flow cytometry with an Epics XL (Beckman-Coulter) after labelling the cells with fluorochrome-conjugated monoclonal antibodies: $\mathrm{CD}_{3}-\mathrm{PC}_{5}$, CD4-RD 1 , CD8-ECD, CD45RA-FITC, CD45RO-FITC, CD19ECD, CD56-PE (Immunotech SAS) corresponding to total T cells $\left(\mathrm{CD}^{+}\right)$, T-helper/inducer $\left(\mathrm{CD}^{+}\right)$, T suppressor/cytotoxic $\left(\mathrm{CD}^{+}\right)$, B lymphocytes $\left(\mathrm{CD} 19^{+}\right)$and natural killer cells $\left(\mathrm{CD} 56^{+}\right)$, respectively. Results are expressed as percentages of total leucocyte populations. Polymorphonuclear leucocyte CD expression was determined by flow cytometry using antiCD11b-FITC and anti-CD18-FITC (Immunotech SAS). Results are expressed as percentages of total leucocyte populations.

When several phenotypic labellings were done in one sample, cells were also labelled with each monoclonal antibody in one-colour immunofluorescence procedure to account for spectral overlap and to adjust compensation settings during flow cytometry analysis. Appropriate conjugated isotype controls were also done in each assay to account for background binding of Ig.

Intra-assay and inter-assay $\mathrm{CV}$ were recorded by using a lyophilised preparation of human immune leucocytes that exhibited surface antigens (Cyto-Trol control cells; Immunotech SAS) and a suspension of fluorospheres of similar size and fluorescence intensity (Flow-Count fluorosphere; Immunotech SAS). Intra-assay and inter-assay CV were less than $2 \%$ for all flow cytometric measurements.

\section{Immune cell isolation}

Immune cells were isolated from the whole blood on a discontinuous Ficoll-Hypaque density gradient (Histopaque ${ }^{\circledR}$ 1077 and 1119; Sigma). Isolated peripheral blood mononuclear cells and polymorphonuclear neutrophil (PMN) suspensions were tested for purity $(>95 \%)$ and viability (>95\%) and adjusted in Roswell Park Memorial Institute (RPMI)-1640 medium (Sigma-Aldrich) to the cell density needed for each test.

\section{Quantification of in vitro IL-2 and soluble IL-2 receptor} production by stimulated lymphocytes

Peripheral blood mononuclear cell suspension $\left(10^{6}\right.$ cells $\left./ \mathrm{ml}\right)$ was incubated for $48 \mathrm{~h}\left(37^{\circ} \mathrm{C}, 5 \% \mathrm{CO}_{2}\right)$ in RPMI-1640 medium supplemented with fresh L-glutamine ( $2 \mathrm{~mm}$; SigmaAldrich), penicillin $(62.5 \mu \mathrm{g} / \mathrm{ml})$, streptomycin $(62.5 \mu \mathrm{g} / \mathrm{ml})$ and $10 \%$ fetal calf serum (Sigma-Aldrich) and containing or not phytohaemagglutinin (PHA) from phaseolus vulgaris $(5 \mu \mathrm{g} / \mathrm{ml}$; Sigma-Aldrich). IL-2 ligand and sIL-2R secretions by lymphocytes were then assayed by ELISA (ELISA kit; Immunotech SAS) at study entry, after depletion and after supplementation.

\section{In vitro polymorphonuclear neutrophil bactericidal activity} and phagocytosis

To assess PMN bactericidal activity and phagocytosis, the PMN suspension $\left(10^{6}\right.$ cells $\left./ \mathrm{ml}\right)$ was stimulated for $10 \mathrm{~min}$ with phorbol myristate acetate (PMA, $10^{-6} \mathrm{M}$; Sigma-Aldrich) or opsonised zymosan $(10 \mathrm{mg} / \mathrm{ml}$; Sigma-Aldrich), respectively. PMN reactive oxygen species (ROS) production was then evaluated by the fluorescence intensity of an intracellular oxidised probe (dihydrorhodamine 123; Sigma-Aldrich), as described previously ${ }^{(24,28)}$. Fluorescence was recorded by flow cytometry (Beckman-Coulter). ROS production by PMA- or opsonised zymosan-stimulated PMN was quantified at study entry, after depletion and after supplementation. Results are expressed as arbitrary units (AU).

\section{In vitro polymorphonuclear neutrophil cell chemotaxis}

PMN chemotaxis was assessed by agarose assay (Indubiose A37; Biosepra) using formyl-methionyl-leucyl-phenylalanine $\left(10^{-7} \mathrm{M}\right.$; Sigma-Aldrich) as chemotactic factor for $90 \mathrm{~min}$ $\left(37^{\circ} \mathrm{C}, 5 \% \mathrm{CO}_{2}\right)$. The distances of cell migration (in $\mathrm{mm}$ ) were then measured microscopically in the direction of the chemoattractant (directed migration, DM) and towards the control (spontaneous migration, SM). Chemotaxis index $(\mathrm{CI}=\mathrm{DM}$ / $\mathrm{SM})$ is expressed as the ratio of directed to SM of PMN cells.

\section{Statistical analysis}

Results are expressed as means with their standard errors. All statistical analyses were run on Statview SAS, version 5 (SAS Institute, Inc.). The experimental design comprised two cross-fixed factors with the factor 'ageing' as six groups and the factor 'nutritional treatment' as three classes (T0: baseline, T1: carotenoid depleted, T2: carotenoid supplemented). This design allowed statistical analysis by two-way repeatedmeasures ANOVA in order to discriminate between the effects of ageing, nutritional treatment, and their interaction. The level of significance was set at $P<0.05$ for this test. When the ANOVA indicated significant interactions, the NewmanKeuls test was used to identify differences between the individual means. When no significant interaction was found, the Newman-Keuls test was used to calculate and compare the marginal means. To assess the correlations between baseline 
biomarkers of immune status and age in our volunteers, Spearman's rank correlation test was used for dependent groups and the Kruskal-Wallis test was used for independent groups.

\section{Results}

Carotenoid intakes and plasma concentrations at baseline and after carotenoid depletion and repletion periods

Baseline plasma carotenoid concentrations were 0.45 (SEM $0.03) \mu \mathrm{mol} / 1$ for $\beta$-carotene, 0.31 (sem 0.01 ) $\mu \mathrm{mol} / 1$ for lycopene and 0.24 (SEM 0.01) $\mu \mathrm{mol} / 1$ for lutein, in agreement with those published previously ${ }^{(29)}$ (Table 1 ). As documented by the food consumption records, the 3-week carotenoid depletion period led to a reduction in fruit, vegetable and potato intake from 472 to $254 \mathrm{~g} / \mathrm{d}$. Under these conditions, plasma levels of $\beta$-carotene, lycopene and lutein were reduced by 35, 52 and $23 \%$, respectively (Table 1 ). After 5 weeks of carotenoid supplementation, plasma $\beta$-carotene, lycopene and lutein concentrations were approximately 4,2 and 1.5 times higher, respectively, compared with the baseline, and 5, 4 and 2 times higher, respectively, compared with the depletion period $(P<0.01 \quad v$. baseline and depletion). Age was positively correlated with fruit and vegetable intake $\left(r^{2} 0 \cdot 12, P=0 \cdot 005\right)$. A positive correlation was also found between age and both $\beta$-carotene $\left(r^{2} 0.32, \quad P=0.01\right)$ and lutein intakes $\left(r^{2} 0 \cdot 21, P=0 \cdot 03\right)$ but not with lycopene intake.

Table 1. Plasma carotenoid concentrations $(\mu \mathrm{mol} / \mathrm{l})$ at baseline (T0) and after carotenoid depletion (T1) and repletion (T2) in the six age groups of healthy volunteers $(n 98)^{\star}$

(Mean values with their standard errors)

\begin{tabular}{|c|c|c|c|c|c|c|}
\hline \multirow[b]{2}{*}{ Age (years) } & \multicolumn{2}{|c|}{$\begin{array}{c}\beta \text {-Carotene } \\
\quad(\text { all-trans) } \\
(\mu \mathrm{mol} / \mathrm{l})\end{array}$} & \multicolumn{2}{|c|}{$\begin{array}{c}\text { Lycopene } \\
\text { (all-trans) } \\
(\mu \mathrm{mol} / \mathrm{l})\end{array}$} & \multicolumn{2}{|c|}{$\begin{array}{c}\text { Lutein } \\
\text { (all-trans) } \\
(\mu \mathrm{mol} / \mathrm{l})\end{array}$} \\
\hline & Mean & SEM & Mean & SEM & Mean & SEM \\
\hline \multicolumn{7}{|l|}{ T0 } \\
\hline $20-29$ & 0.333 & 0.043 & 0.380 & 0.021 & 0.220 & 0.010 \\
\hline $30-39$ & 0.385 & 0.034 & 0.369 & 0.032 & 0.195 & 0.016 \\
\hline $40-49$ & 0.345 & 0.034 & 0.269 & 0.023 & 0.221 & 0.016 \\
\hline $50-59$ & 0.534 & 0.059 & 0.388 & 0.035 & 0.305 & 0.023 \\
\hline $60-69$ & 0.608 & 0.055 & 0.238 & 0.025 & 0.281 & 0.019 \\
\hline $70-75$ & 0.487 & 0.081 & 0.195 & 0.038 & 0.201 & 0.022 \\
\hline $20-75$ & $0.449^{b}$ & 0.021 & $0.317^{\mathrm{b}}$ & 0.012 & $0.242^{b}$ & 0.008 \\
\hline \multicolumn{7}{|l|}{$\mathrm{T} 1$} \\
\hline $20-29$ & 0.203 & 0.024 & 0.181 & 0.010 & 0.171 & 0.009 \\
\hline $30-39$ & 0.242 & 0.020 & 0.154 & 0.012 & 0.154 & 0.010 \\
\hline $40-49$ & 0.224 & 0.022 & 0.125 & 0.010 & 0.167 & 0.013 \\
\hline $50-59$ & 0.372 & 0.037 & 0.177 & 0.016 & 0.242 & 0.017 \\
\hline $60-69$ & 0.392 & 0.034 & 0.129 & 0.014 & 0.199 & 0.012 \\
\hline $70-75$ & 0.309 & 0.037 & 0.090 & 0.015 & 0.157 & 0.016 \\
\hline $20-75$ & $0.288^{a}$ & 0.013 & $0 \cdot 150^{\mathrm{a}}$ & 0.006 & $0 \cdot 185^{\mathrm{a}}$ & 0.006 \\
\hline \multicolumn{7}{|l|}{ T2 } \\
\hline $20-29$ & 1.293 & 0.145 & 0.601 & 0.032 & 0.355 & 0.023 \\
\hline $30-39$ & 1.647 & 0.149 & 0.643 & 0.043 & 0.362 & 0.023 \\
\hline $40-49$ & 1.832 & 0.218 & 0.633 & 0.043 & 0.411 & 0.028 \\
\hline $50-59$ & 1.792 & 0.137 & 0.656 & 0.044 & 0.490 & 0.034 \\
\hline $60-69$ & 1.838 & 0.161 & 0.523 & 0.031 & 0.404 & 0.022 \\
\hline $70-75$ & 1.649 & 0.206 & 0.548 & 0.058 & 0.343 & 0.040 \\
\hline $20-75$ & $1.683^{\mathrm{c}}$ & 0.070 & $0.605^{c}$ & 0.017 & $0.402^{c}$ & 0.011 \\
\hline
\end{tabular}

$\overline{a, b, c}$ Mean values with unlike superscript letters were significantly different $(P<0.05$ for the same carotenoid studied).

${ }^{*}$ Repeated-measures ANOVA + Newman-Keuls test were used.

\section{Serum biomarkers of immune status}

Among all biomarkers of immune function tested (IgG, IgA, IgM, C3, C4 and sIL-2R), none was affected by the dietary intervention with carotenoids (Table 2 ). In addition, none of these biomarkers was affected by ageing except for IgA levels, which were positively correlated with age at baseline $\left(r^{2} 0 \cdot 013, P<0 \cdot 05\right)$. Accordingly, an age effect was found only for serum IgA levels, which were increased with age (Fig. 1).

\section{Delayed-type hypersensitivity responses}

Considering the DTH responses, the number of positive reactions was significantly higher in the younger group (20-29 years) and, surprisingly, also in the older group (70-75 years) (Fig. 2(A)). We also observed an increase in the DTH score in the older group (Fig. 2(B)). DTH responses were not affected by carotenoid status in our subjects, and this was observed whatever the antigen used (Table 3).

\section{Leucocyte phenotypes}

The proportion (\%) of CD3, CD4 and CD8 lymphocytes was modified neither by age (data not shown) nor by dietary intervention with carotenoids (Table 4). Ageing was associated with a lower percentage of B lymphocytes (Fig. 3(A)) and NK lymphocytes were proportionally higher in elderly subjects than in young adults (Fig. 3(B)). At baseline, NK lymphocytes were positively correlated with age $\left(r^{2} 0 \cdot 157, P<0 \cdot 01\right)$.

Distribution between naive (CD4-CD45RA ${ }^{+}$) and memory $\left(\mathrm{CD} 4-\mathrm{CD} 45 \mathrm{RO}^{+}\right) \mathrm{T} 4$ cells was modified by ageing (Figs. 4(A) and (B), respectively). As expected, the percentage of CD4CD45 $\mathrm{RA}^{+}$was higher in young adults than in elderly subjects, and conversely, the percentage of $\mathrm{CD} 4-\mathrm{CD} 45 \mathrm{RO}^{+}$cells was lower in young adults than in older subjects. Accordingly, CD4-CD45RA ${ }^{+}$cells were negatively correlated with age at baseline $\left(r^{2}-0 \cdot 178, P<0 \cdot 05\right)$, whereas CD $4-\mathrm{CD} 45 \mathrm{RO}^{+}$cells were positively correlated with age at baseline $\left(r^{2} 0 \cdot 194\right.$, $P<0 \cdot 05)$.

For each age group, there was no effect of dietary intervention on B cells, NK cells (Figs. 3(A) and (B)), CD4-CD 45RA ${ }^{+}$ or $\mathrm{CD} 4-\mathrm{CD} 45 \mathrm{RO}^{+}$cells (Figs. 4(A) and (B)). However, when all patients were taken as a group, the percentage of $\mathrm{CD}^{4} 5 \mathrm{RO}^{+}$cells was significantly decreased after a 5-week repletion (T0: $59 \cdot 6$ (SEM 1.3); T1: $60 \cdot 4$ (SEM 1.4); T2: $53 \cdot 8$ (SEM $1 \cdot 1) ; P<0.05$ T2 $v$. T0 or T1).

The percentage of adhesion antigens (CD11b, CD18) of human PMN was not affected, neither by carotenoid status (T0: 98.7 (SEM 0.2); T1. $99 \cdot 2$ (SEM 0.9); T2: $98 \cdot 7$ (SEM 0.3) for CD11b and T0: 99.1 (sem 0.3); T1: $99 \cdot 6$ (sem 0.1); T2: $99 \cdot 7$ (sem $0 \cdot 1$ ) for CD18), nor by the age of the volunteers (data not shown).

\section{Blood leucocyte functions}

In vitro $I L-2$ and soluble $I L-2$ receptor production by stimulated lymphocytes. To assess lymphocyte proliferation, we measured the in vitro production of both IL-2 ligand and 
Table 2. Serum immune parameters at baseline (T0) and after carotenoid depletion (T1) and repletion (T2) in healthy volunteers $(n 98)^{*}$

(Mean values with their standard errors)

\begin{tabular}{|c|c|c|c|c|c|c|c|}
\hline & \multicolumn{2}{|c|}{ T0 } & \multicolumn{2}{|c|}{$\mathrm{T} 1$} & \multicolumn{2}{|c|}{ T2 } & \multirow[b]{2}{*}{ ANOVA } \\
\hline & Mean & SEM & Mean & SEM & Mean & SEM & \\
\hline $\lg G(g / l)$ & $11 \cdot 1$ & 0.2 & $11 \cdot 3$ & 0.2 & $11 \cdot 1$ & 0.2 & NS \\
\hline $\lg A(g / /)$ & 2.56 & 0.1 & 2.58 & $0 \cdot 1$ & $2 \cdot 61$ & 0.1 & A \\
\hline $\lg M(g / l)$ & 1.22 & 0.06 & 1.23 & 0.06 & 1.23 & 0.06 & NS \\
\hline C3 (g/l) & 0.99 & 0.02 & 0.99 & 0.02 & 1.02 & 0.02 & NS \\
\hline C4 (g/l) & 0.23 & 0.007 & 0.23 & 0.006 & 0.24 & 0.01 & NS \\
\hline sIL-2R (рм) & $38 \cdot 3$ & 1.8 & 37.4 & 1.6 & $38 \cdot 7$ & $1 \cdot 7$ & NS \\
\hline
\end{tabular}

sIL-2R by lymphocytes stimulated with PHA for $48 \mathrm{~h}$. Whatever the age of the volunteers, carotenoid depletion induced an increase in the secretion of both IL-2 (T0: 59 (SEM 11) pg/l; T1: 80 (sEm 14) pg/l) and sIL-2R (T0: 333 (sEM 19) pmol/1; T1: 382 (sEm 24) pmol/1), although this increase was not significant. After repletion, production of $\mathrm{IL}-2$ and sIL-2R returned to baseline values (57 (SEM 10) pg/l and 296 (SEM 19) pmol/l, respectively). Moreover, age affected significantly the production of IL-2 by lymphocytes (Fig. 5(A)) but not that of sIL-2R (Fig. 5(B)). At baseline, IL-2 production was positively correlated with age $\left(r^{2} 1 \cdot 228, P<0 \cdot 01\right)$.

Polymorphonuclear neutrophil oxidative response. ROS production by stimulated PMN was significantly enhanced after carotenoid depletion (from 81.5 (SEM 4.7) at baseline to 134.8 (SEM 6.8), $P<0 \cdot 001$ ) independently of age (Table 5). Carotenoid repletion restored this production to a value (87.2 (SEM 4.7)) equivalent to the baseline. Phagocytosis was not affected by carotenoid status (Table 5).

PMN bactericidal activity was higher in subjects from any age group $<50$ years compared with those from any age group $\geq 50$ years at baseline (93.6 (SEM 6.2) v. 66.5 (SEM 5.4) AU, respectively, $P=0 \cdot 003$ ), after depletion (155.6 (SEM 10.2) v. 109.1 (SEM 6.7) AU, respectively, $P=0.007$ ) and after repletion (94.9 (sEM 6.9) v. $77 \cdot 6$ (sem 5.8) AU, respectively, $P=0 \cdot 1$ ) (Table 5 and Fig. 6(A)). In contrast, phagocytosis was not affected by ageing (data not shown)
Polymorphonuclear neutrophil chemotaxis. n the ninetyeight volunteers taken as a group, DM towards formylmethionyl-leucyl-phenylalanine was significantly diminished after both dietary carotenoid restriction and depletion $v$. baseline (Table 5), whereas SM and CI were not affected by ageing (data not shown) nor by carotenoid status (Table 5). When each age group was considered separately, the CI (DM/SM) was not modified by carotenoid repletion/depletion. On the other hand, the CI significantly increased in the 70-75-year-old group, as a result of a decrease in SM in this age group (Fig. 6(B)).

\section{Discussion}

The decline in immune function with age is unanimously recognised and supported by epidemiological and clinical studies ${ }^{(30)}$. However, the age-related changes have led to conflicting results and these discrepancies may be partially ascribed to the population tested, i.e. presence of concomitant pathological disorders or nutritional deficiencies that may affect immune status. To overcome this problem, volunteers in the present study were recruited according to the SENIEUR protocol developed in 1984 by a collaborative study group as an attempt to define the criteria for selecting truly healthy aged individuals for immunogerontological studies ${ }^{(25)}$. This protocol sets forth strict health guidelines based on clinical and laboratory data in an effort to reduce the bias present in other studies; that is,

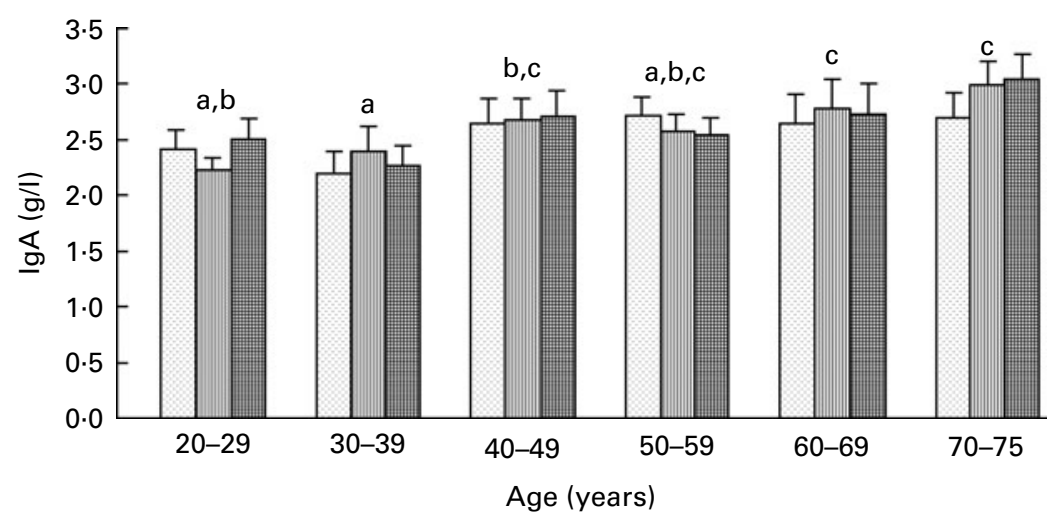

Fig. 1. Effects of age and carotenoid depletion-repletion on IgA serum levels. Values are means, with standard errors represented by vertical bars. Statistical analysis by ANOVA and Newman-Keuls test; IgA serum levels were increased with age (a\#b and b\#c, $P<0.05$, statistical significance by age related to all three study periods) but were not affected by carotenoid status. T0, baseline ( $\square$ ); T1, depletion ( $\square$ ); T2, repletion (满). 

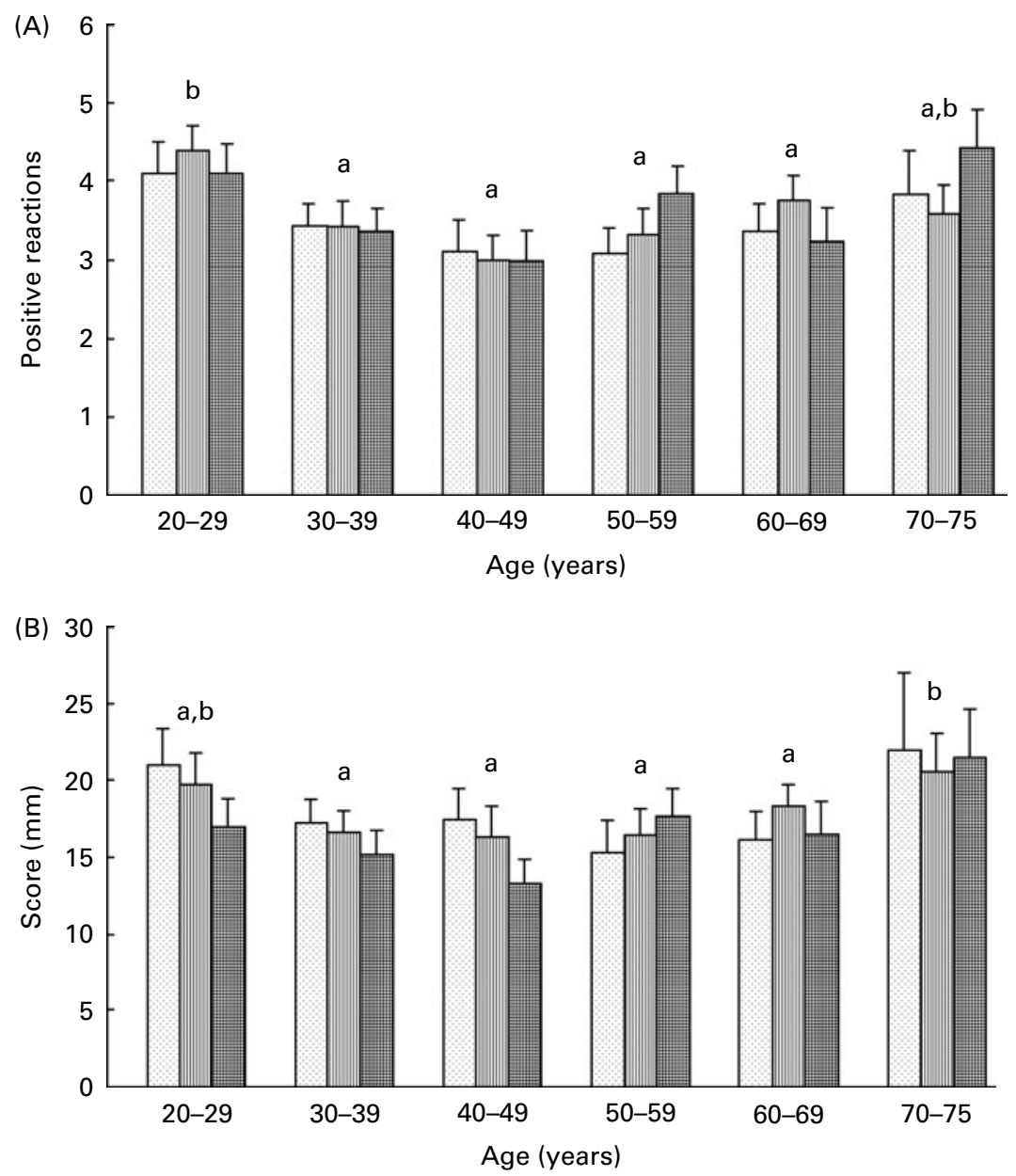

Fig. 2. Effects of age and carotenoid depletion-repletion on the delayed-type hypersensitivity (DTH) skin test response. (A) Antigen positive reactions and (B) cumulative score. Values are means, with standard errors represented by vertical bars. Statistical analysis by ANOVA and Newman-Keuls test: (A) the number of positive reactions was significantly higher in the younger group (20-29 years) and also in the older group (70-75 years) (a\#b, $P<0.05$, statistical significance by age related to all three study periods) and (B) an increase in the DTH score was also observed in the older group (a\#b, $P<0.05$, statistical significance by

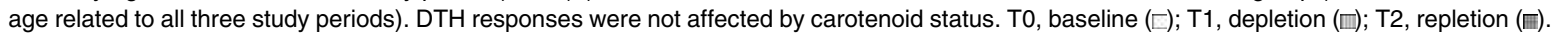

Table 3. Delayed hypersensitivity (DTH) at baseline (T0) and after carotenoid depletion (T1) and repletion (T2) in healthy volunteers $(n 98)^{*}$

(Mean values with their standard errors)

\begin{tabular}{|c|c|c|c|c|c|c|c|}
\hline & \multicolumn{2}{|c|}{ T0 } & \multicolumn{2}{|c|}{ T1 } & \multicolumn{2}{|c|}{ T2 } & \multirow[b]{2}{*}{ ANOVA } \\
\hline & Mean & SEM & Mean & SEM & Mean & SEM & \\
\hline $\begin{array}{l}\text { Number of positive reactions } \\
\text { Induration diameters }(\mathrm{mm})\end{array}$ & 3.45 & 0.22 & 3.60 & 0.14 & 3.58 & 3.60 & $A$ \\
\hline Proteus mirabilis & 2.42 & 0.20 & $2 \cdot 31$ & 0.23 & $2 \cdot 65$ & $0 \cdot 19$ & NS \\
\hline Trichophyton & 0.88 & $0 \cdot 17$ & 0.89 & $0 \cdot 19$ & 1.26 & 0.21 & NS \\
\hline Candida albicans & $2 \cdot 36$ & 0.25 & 2.69 & 0.27 & $2 \cdot 33$ & 0.24 & NS \\
\hline Tetanus & $4 \cdot 18$ & 0.36 & 3.71 & 0.29 & $2 \cdot 61$ & 0.26 & NS \\
\hline Diphtheria & 1.53 & 0.25 & 1.43 & 0.22 & 1.04 & $0 \cdot 18$ & NS \\
\hline Streptococcus & 0.93 & 0.20 & 1.43 & 0.22 & 1.08 & $0 \cdot 18$ & NS \\
\hline Tuberculin & $5 \cdot 36$ & 0.34 & $5 \cdot 35$ & 0.32 & $5 \cdot 18$ & 0.33 & NS \\
\hline Cumulative score $=$ sum & $17 \cdot 7$ & 0.9 & $17 \cdot 8$ & 0.7 & $16 \cdot 3$ & 0.7 & A \\
\hline
\end{tabular}

* Two-way repeated-measures ANOVA was performed to discriminate among the effects of age $(\mathrm{A} ; P<0.05)$, and dietary intervention $(\mathrm{N} ; \mathrm{P}<0.05)$. None of the DTH parameters varied in function of the diet. 
Table 4. Lymphocyte distribution (\%) at baseline (T0) and after carotenoid depletion (T1) and repletion (T2) in healthy volunteers $(n 98)^{*}$

(Mean values with their standard errors)

\begin{tabular}{|c|c|c|c|c|c|c|c|}
\hline & \multicolumn{2}{|c|}{ T0 } & \multicolumn{2}{|c|}{$\mathrm{T} 1$} & \multicolumn{2}{|c|}{ T2 } & \multirow[b]{2}{*}{ ANOVA } \\
\hline & Mean & SEM & Mean & SEM & Mean & SEM & \\
\hline \multicolumn{8}{|l|}{ T lymphocytes (\%) } \\
\hline Total & 73.9 & $0 \cdot 6$ & 73.9 & 0.6 & $74 \cdot 1$ & 0.6 & NS \\
\hline $\mathrm{CD}^{+}{ }^{+}$ & $44 \cdot 6$ & 0.7 & $45 \cdot 4$ & 0.7 & $45 \cdot 8$ & 0.7 & NS \\
\hline $\mathrm{CD}^{+}$ & $30 \cdot 1$ & 0.8 & $30 \cdot 1$ & 0.8 & $30 \cdot 3$ & 0.7 & NS \\
\hline B lymphocytes (\%) & $12 \cdot 9$ & 0.4 & $12 \cdot 2$ & 0.4 & $11 \cdot 7$ & 0.4 & A \\
\hline NK lymphocytes (\%) & $14 \cdot 1$ & 0.6 & $14 \cdot 7$ & 0.7 & $14 \cdot 8$ & 0.6 & A \\
\hline
\end{tabular}

the confusion between observed phenomena caused by the natural process of healthy ageing, and phenomena attributed to age-related disease.

\section{Age effect}

In our well-defined healthy population, we found that serum IgA levels were higher in the elderly subjects, which is in agreement with other studies ${ }^{(31)}$ and suggests either a complex derangement of $\mathrm{B}$ cell function with age ${ }^{(32)}$ or a remodelling of the immune system rather than a deterioration ${ }^{(33)}$. By recruiting only male volunteers in the present study, we have excluded any possible influence of immune status by hormonal changes that occur with age in women. We also found alterations in immune capacity reflected by a greater proportion of NK cells, a decrease in B lymphocytes but a stable number of $\mathrm{T}$ cells. Moreover, a shift from a predominance of naive $\mathrm{T}$ cells towards $\mathrm{T}$ cells expressing memory phenotypes was observed from the youngest to the oldest age groups, as reported previously $^{(34,35)}$. This shift may result from the age-related repetition of antigenic challenges. As previously reported ${ }^{(35)}$, proportions of cells expressing CD11b and CD18 (in \%) were not statistically different between young adults and older subjects. Concerning lymphocyte function, only IL-2 production by lymphocytes was significantly increased with age. As IL-2 is a major stimulator of the clonal expansion of NK cells, it might contribute to the enhancement of NK cell phenotype observed among the elderly. The present results contrast with another study performed in 65-85-year-old individuals whose immune functions, as measured by lymphocyte proliferation and in vitro IL-2 release from PHA-stimulated lymphocyte cultures, were comparable with those of young adults aged 20-30 years ${ }^{(36)}$. In the present study, the PMN bactericidal activity, assessed by ROS production in response to PMA activation, was significantly impaired with age, with a marked
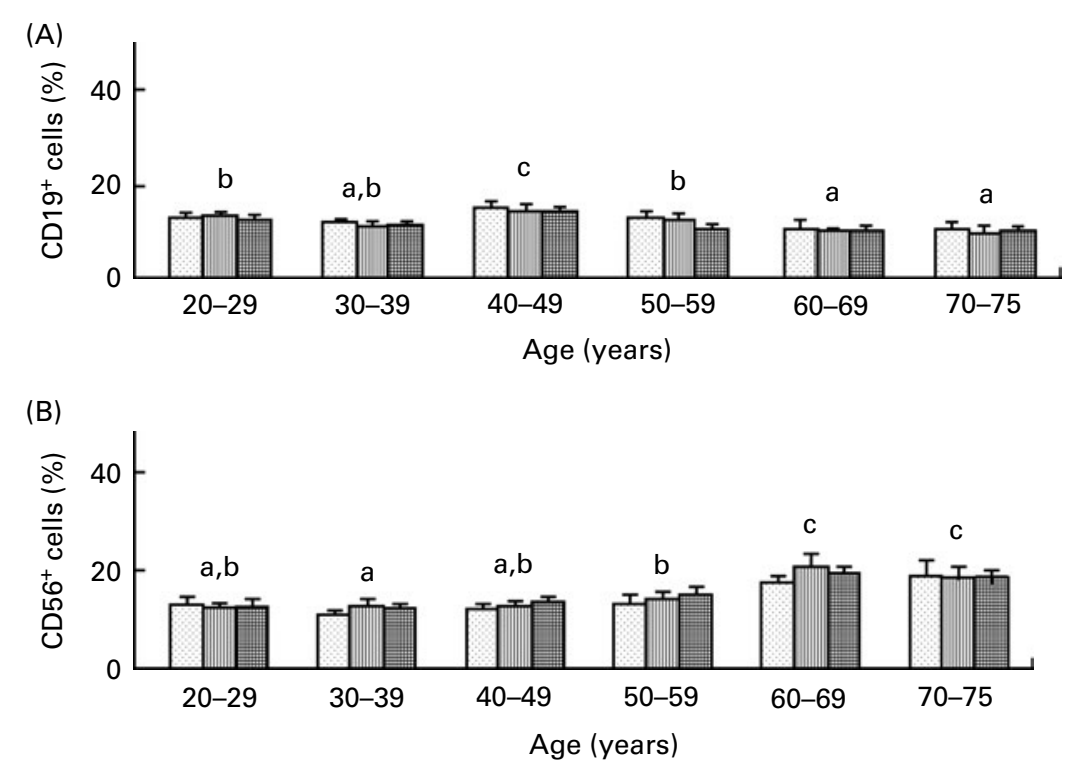

Fig. 3. Effects of age and carotenoid depletion-repletion on the percentage of (A) B cells and (B) natural killer (NK) cells. Values are means, with standard errors represented by vertical bars. Statistical analysis by ANOVA and Newman-Keuls test: (A) the percentage of B lymphocytes decreased with age (a\#b and b\#c, $P<0.05$, statistical significance by age related to all three study periods) and (B) the percentage of NK lymphocytes was proportionally higher in elderly subjects than in young adults ( $\mathrm{a \# b}$ and $\mathrm{b \# c}, P<0.05$, statistical significance by age related to all three study periods). The percentages of $\mathrm{B}$ and NK cells were not affected by carotenoid status. T0, baseline $(\square)$; T1, depletion $(\square)$; T2, repletion (目). 

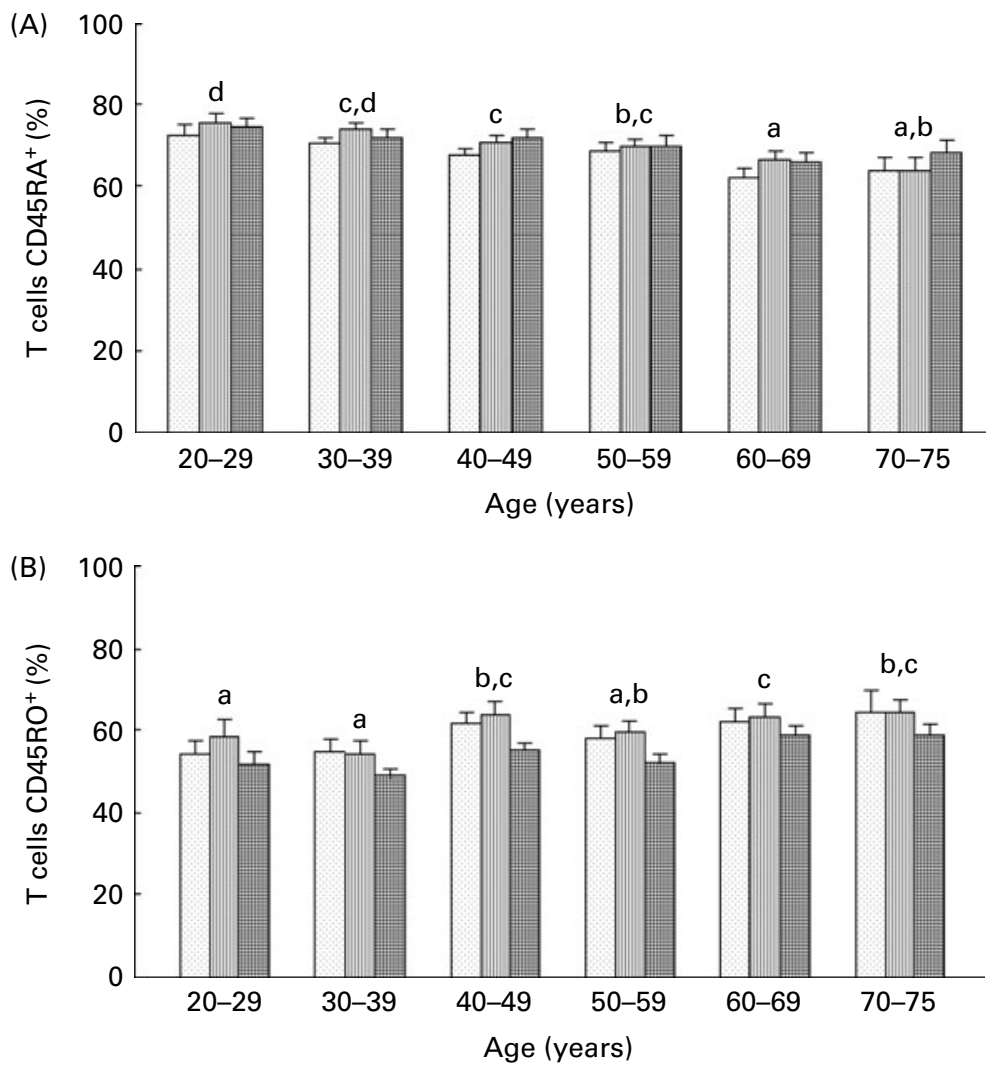

Fig. 4. Effects of age and carotenoid depletion-repletion on the percentage of $(A) C D 45 R A^{+}$and (B) $C D 45 R O^{+}$cells. Values are means, with standard errors represented by vertical bars. Statistical analysis by ANOVA and Newman-Keuls test: (A) the percentage of CD4-CD45RA ${ }^{+}$cells was higher in young adults than in elderly subjects (a\#b, b\#c and $c \# d, P<0.05$, statistical significance by age related to all three study periods) and (B) conversely, the percentage of $\mathrm{CD} 4-\mathrm{CD} 45 \mathrm{RO}^{+}$cells was lower in young adults than in older subjects (a\#b and b\#c, $P<0.05$, statistical significance by age related to all three study periods). The percentage of CD4-CD45RA ${ }^{+}$cells was not affected by carotenoid status whereas that of $C D 4-C D 45 R O^{+}$cells was significantly decreased after repletion,

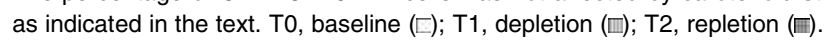

cut-off from 50 years old. PMA is a lipophilic agent that directly activates NADPH oxidase, a key enzyme of the oxidative burst, by enhancing protein kinase $\mathrm{C}$ and thus stimulates the production of ROS. This implies that the cell response loses adaptive capacity with ageing. In addition, the capacity of neutrophils to migrate spontaneously is impaired in the older age group $(70+$ years), resulting in a higher CI.

DTH skin tests assess cell-mediated immune function in vivo. The DTH response involves T cells and macrophages without involving $\mathrm{B}$ cells and gives a measure of the individual ability to develop a cell-mediated immune response when challenged with a subcutaneous injection of a group of antigens to which they have been previously exposed. We observed enhanced DTH responses in the younger group (20-29 years) and, surprisingly, also in the older group (60-75 years). This result may be explained by good vaccination status in young adults and could be linked to booster doses in elderly people.

\section{Dietary effect}

In the present study, we also analysed the immune status and functions after depletion and repletion of carotenoids which are powerful antioxidants protecting the cells from damage caused by free radicals. Carotenoids, in particular $\beta$-carotene, are also believed to enhance the functions of the immune system. The observation that $\beta$-carotene has immuno-enhancing effects independent of its conversion to vitamin $\mathrm{A}^{(37)}$ has stimulated interest in the possible immunoenhancing effect of other carotenoids such as lycopene and lutein with basal plasma concentrations that are 2- to 5-fold lower than those of $\beta$-carotene ${ }^{(21,24)}$. In healthy male nonsmokers, $26 \mathrm{~d}$ supplementation with lycopene or lutein (15 mg daily) did not have an impact on the expression of monocyte surface molecules as significantly as did $\beta$-carotene supplementation at the same dose ${ }^{(22)}$. Moreover, in healthy elderly human subjects, a 12-week supplementation with low doses of lycopene $(13 \mathrm{mg})$ and $\beta$-carotene $(8 \mathrm{mg})$ did not significantly alter the in vitro proliferation of PHA-stimulated peripheral blood mononuclear cells ${ }^{(23)}$. In the present study, with higher doses of lycopene and $\beta$-carotene ( 15 and $30 \mathrm{mg}$, respectively), IL-2 production in PHA-stimulated peripheral blood mononuclear cells was not significantly altered. Actually, only a few specific immunity-related parameters were statistically modified by changing the level of carotenoid intake and status. In lymphocytes, both carotenoid deficiency and excess have been suggested to affect the expression of various genes and the risk of genome instability, and to inhibit cell growth ${ }^{(38,39)}$. Here, we found that $\mathrm{CD} 45 \mathrm{RO}^{+}$cell distribution was decreased 

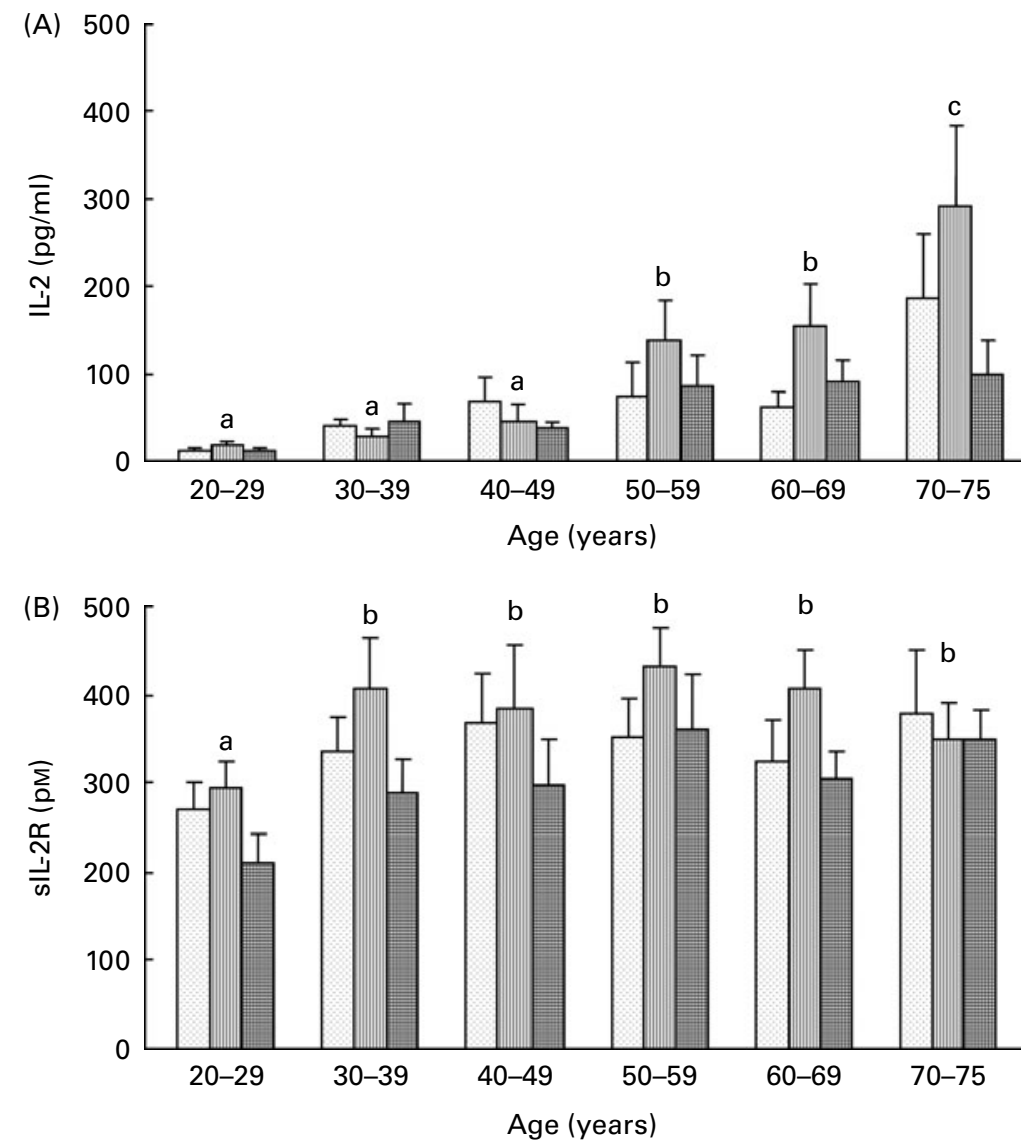

Fig. 5. Effects of age and carotenoid depletion-repletion on (A) IL-2 and (B) soluble IL-2 receptor (sIL-2R) production from phytohaemagglutinin-stimulated lymphocytes ex vivo. Values are means, with standard errors represented by vertical bars. Statistical analysis by ANOVA and Newman-Keuls test: (A) the production of IL-2 by lymphocytes was significantly increased with age (a\#b and b\#c, $P<0.05$, statistical significance by age related to all three study periods) and (B) the production of sIL-2R was barely affected in function of age (a\#b, $P<0.05$, statistical significance by age related to all three study periods). In most of the age groups, carotenoid depletion induced an increase in the secretion of both IL-2 and SIL-2R, although this increase was not significant. After repletion, production of IL-2 and sIL-2R returned to baseline values. T0, baseline ( $\square$ ); T1, depletion (ㅍ); T2, repletion (피).

after carotenoid supplementation, suggesting that additional carotenoid intake may have an inhibiting effect in these cells. Concerning lymphocyte function, sIL-2R production was increased after carotenoid depletion and then returned to baseline after supplementation. The release of this soluble form of membrane-bound IL-2R by ex vivo activated cells is considered as a marker of cell activation. Although it can bind to IL-2, it does so with a low affinity, enabling it to compete

Table 5. Blood polymorphonuclear neutrophil functions at baseline (T0) and after carotenoid depletion (T1) and repletion (T2) in healthy volunteers $(n 98)^{*}$

(Mean values with their standard errors)

\begin{tabular}{|c|c|c|c|c|c|c|c|}
\hline & \multicolumn{2}{|c|}{ T0 } & \multicolumn{2}{|c|}{ T1 } & \multicolumn{2}{|c|}{$\mathrm{T} 2$} & \multirow[b]{2}{*}{ ANOVA } \\
\hline & Mean & SEM & Mean & SEM & Mean & SEM & \\
\hline \multicolumn{8}{|l|}{ ROS production } \\
\hline Bactericidal activity (AU)† & $81 \cdot 5^{a}$ & $4 \cdot 7$ & $134 \cdot 8^{\mathrm{b}}$ & $6 \cdot 8$ & $87 \cdot 2^{a}$ & $4 \cdot 7$ & $\mathrm{~A}, \mathrm{~N}$ \\
\hline Age $<50$ years & $93 \cdot 6^{a}$ & $6 \cdot 2$ & $155 \cdot 6^{\mathrm{b}}$ & $10 \cdot 2$ & $94.9^{a}$ & 6.9 & \\
\hline Age $\geq 50$ years & $66 \cdot 5^{\mathrm{a}}$ & $5 \cdot 4$ & $109 \cdot 1^{b}$ & $6 \cdot 7$ & $77 \cdot 6^{\mathrm{a}}$ & $5 \cdot 8$ & \\
\hline Phagocytosis (AU) & 4.09 & 0.14 & $4 \cdot 20$ & 0.14 & 4.47 & 0.13 & NS \\
\hline \multicolumn{8}{|l|}{ Chemotaxis } \\
\hline $\mathrm{DM}(\mathrm{mm}) \dagger$ & $17 \cdot 9^{b}$ & 0.4 & $16 \cdot 3^{\mathrm{a}}$ & 0.4 & $16 \cdot 1^{\mathrm{a}}$ & 0.4 & $\mathrm{~N}$ \\
\hline $\mathrm{SM}(\mathrm{mm})$ & 3.7 & 0.2 & $3 \cdot 3$ & 0.2 & 3.0 & 0.2 & $A$ \\
\hline Cl (DM/SM) & $6 \cdot 95$ & 0.48 & $6 \cdot 70$ & 0.48 & $7 \cdot 91$ & 0.54 & $A$ \\
\hline
\end{tabular}

ROS, reactive oxygen species; $\mathrm{AU}$, arbitrary units; DM, directed migration; SM, spontaneous migration; $\mathrm{Cl}$, chemotaxis index.

a,b Mean values with unlike superscript letters were significantly different.

* Two-way repeated-measures ANOVA was performed to discriminate among the effects of age $(A ; P<0.05)$, and dietary intervention $(\mathrm{N} ; P<0.05)$.

†Bactericidal activity and DM varied in function of the diet $(P<0.0001$ and $P<0.01$, respectively). 

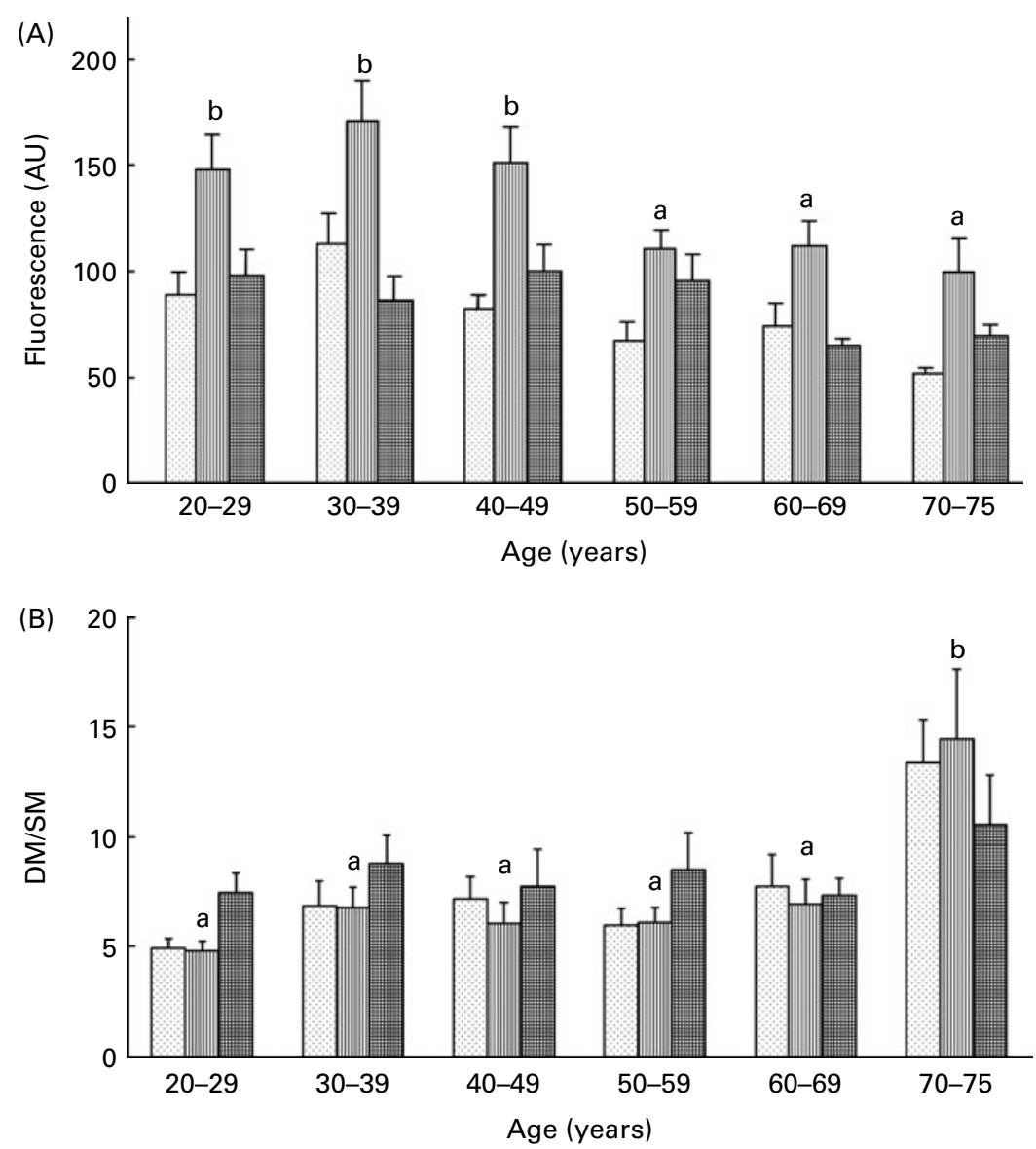

Fig. 6. Effects of age and carotenoid depletion-repletion on reactive oxygen species (ROS) production from (A) phorbol myristate acetate (PMA)-stimulated polynuclear neutrophils (PMN) ex vivo and (B) PMN chemotaxis index. Values are means, with standard errors represented by vertical bars. Statistical analysis by ANOVA and Newman-Keuls test: (A) ROS production from PMA-stimulated PMN decreased with age (a\#b, $P<0.05$, statistical significance by age related to all three study periods) and a cut-off was observed from 50 years onwards. This ROS production was significantly enhanced after carotenoid depletion and restored to the baseline after carotenoid repletion, as indicated in the text and in Table 5 and (B) PMN chemotaxis index was affected by age only in the older age group (a\#b, $P<0.05$, statistical significance by age related to all three study periods). However, the chemotaxis index was not affected by carotenoid status. T0, baseline ( $\square$ ); T1, depletion (I); T2, repletion (II). AU, arbitrary units; DM, directed migration; SM, spontaneous migration.

with IL-2 binding to high-affinity receptors on the cell surface. It has no physiological role except of being a marker of activated cells ${ }^{(40)}$. The present results contrast with those obtained by Daudu et al. ${ }^{(6)}$ who found that neither depletion nor repletion of $\beta$-carotene significantly affected in vitro secretion of SIL$2 \mathrm{R}$. This discrepancy can be explained by methodological differences such as the duration of depletion (68v.21d), the daily dose of $\beta$-carotene supplementation $(9 v .30 \mathrm{mg}$ ), the number (12v.98) and the sex (female $v$. male) of subjects. Considering the non-specific immune system, the present data reveal that variations in carotenoid intake alter some but not all neutrophil functions. DM of neutrophils towards formylmethionyl-leucyl-phenylalanine was reduced after the relatively short-term dietary carotenoid restriction and after carotenoid repletion. While neutrophil phagocytosis was not influenced by the restriction in our conditions, the bactericidal capacity was dramatically increased. We observed that PMAstimulated PMN from carotenoid-depleted subjects had an increased ROS content, supporting the protective properties of carotenoids at physiological levels against oxidative stress $^{(41)}$. However, the high ROS content in PMN might also be explained by an imbalance between the production of ROS and antioxidant molecules present in the cell. In addition, in vivo carotenoid repletion normalised the ROS content in PMN. This observation clearly demonstrates that carotenoids modulate the amount of ROS in PMN during oxidative burst, possibly by a quenching effect. However, some authors ${ }^{(42)}$ observed that repletion with $\beta$-carotene $(15 \mathrm{mg} / \mathrm{d}$ during 4 weeks) of previously carotenoid-depleted healthy male adults did not affect superoxide production by PMA-stimulated PMN. In this latter study, in spite of a lack of variation in ROS production, supplementation with $\beta$-carotene reduced serum lipid peroxide concentrations and an inverse relationship between serum $\beta$-carotene and lipid peroxide levels was also noted $^{(42)}$. Another hypothesis for the effects of carotenoids on PMN ROS concentration could be a modulatory effect of these micronutrients on the enzyme activities implicated in the ROS biochemical pathway. Dixon et al. ${ }^{(43)}$ evaluated, in adult women, the effects of carotenoid depletion (68d) and repletion ( $15 \mathrm{mg} / \mathrm{d}$ during $28 \mathrm{~d}$ ) on erythrocyte superoxide dismutase activity. This activity was depressed in carotenedepleted women and recovered with repletion. Inversely, 
Girodon et al $^{\left({ }^{(44)}\right.}$ failed to show any modification of the superoxide dismutase activity in human subjects receiving $\beta$-carotene supplementation $(6 \mathrm{mg} / \mathrm{d})$ during 2 years. The biological effects of carotenoids on the ROS biochemical pathway may be limited by the cellular concentration of other antioxidants and ROS precursors. These latter points need to be elucidated by additional studies. Finally, we found that DTH responses were not altered after carotenoid depletion and repletion periods, suggesting that there is no relationship between carotenoid status and DTH responses during ageing.

In conclusion, the present data confirm the age-related impairment of the immune response, in particular PMN bactericidal activity, in healthy human subjects. In addition, the present study suggests that in well-nourished healthy individuals, bactericidal activity may be modulated by carotenoids in the absence of an age effect. The present results emphasise the importance of an optimal carotenoid supply to limit the detrimental effects of neutrophil oxidative burst, especially in undernourished people and particularly in the elderly.

\section{Acknowledgements}

The authors thank the volunteers who participated in the study. They are also greatly indebted to the clinical staff, to Dr Corinne Bouteloup (CRNH Auvergne) for her medical assistance, and to Dr Stéphane Perrier for improving the English rendition of the manuscript. This study was carried out with financial support from the Commission of the European Communities, specific RTD programme 'Quality of Life and Management of Living Resources', QLK1-CT-1999-00 830, VITAGE. The authors' responsibilities were as follows: J. R., B. W.-R., E. R., M.-P. V. were involved in the coordination and design of the experiments; M.-C. F., R. M.-Q., S. W., E. T., E. R. and M.-P. V. contributed to the collection and analysis of the data; M.-P. V. participated in the writing of the manuscript and provision of significant advice. All authors read and approved the final manuscript. None of the authors had a personal or financial conflict of interest.

\section{References}

1. Hughes DA (2001) Dietary carotenoids and human immune function. Nutrition 17, 823-827.

2. Chew BP \& Park JS (2004) Carotenoid action on the immune response. J Nutr 134, 257S-261S.

3. Mayne ST (1996) Beta-carotene, carotenoids, and disease prevention in humans. FASEB J 10, 690-701.

4. Cooper DA (2004) Carotenoids in health and disease: recent scientific evaluations, research recommendations and the consumer. J Nutr 134, 221S-224S.

5. Rock E, Winklhofer-Roob BM, Ribalta J, et al. (2001) Vitamin A, vitamin $\mathrm{E}$ and carotenoid status and metabolism during ageing: functional and nutritional consequences (VITAGE PROJECT). Nutr Metab Cardiovasc Dis 11, 4 Suppl., 70-73.

6. Daudu PA, Kelley DS, Taylor PC, et al. (1994) Effect of low beta-carotene diet on the immune functions of adult women. Am J Clin Nutr 60, 969-972.

7. Watzl B, Bub A, Briviba K, et al. (2003) Supplementation of a low-carotenoid diet with tomato or carrot juice modulates immune functions in healthy men. Ann Nutr Metab $\mathbf{4 7}$, $255-261$.

8. Moriguchi S, Okishima N, Sumida S, et al. (1996) Betacarotene supplementation enhances lymphocyte proliferation with mitogens in human peripheral blood lymphocytes. Nutr Res 16, 211-218.

9. Hughes DA, Wright AJ, Finglas PM, et al. (1997) The effect of beta-carotene supplementation on the immune function of blood monocytes from healthy male nonsmokers. J Lab Clin Med 129, 309-317.

10. Alexander M, Newmark H \& Miller RG (1985) Oral betacarotene can increase the number of OKT4t cells in human blood. Immunol Lett 9, 221-224.

11. Watson RR, Prabhala RH, Plezia PM, et al. (1991) Effect of beta-carotene on lymphocyte subpopulations in elderly humans: evidence for a dose-response relationship. $\mathrm{Am} \mathrm{J}$ Clin Nutr 53, 90-94.

12. Ringer TV, De Loof MJ, Winterrowd GE, et al. (1991) Betacarotene's effects on serum lipoproteins and immunologic indices in humans. Am J Clin Nutr 53, 688-694.

13. Gossage C, Deyhim M, Moser-Veillon PB, et al. (2000) Effect of beta-carotene supplementation and lactation on carotenoid metabolism and mitogenic $\mathrm{T}$ lymphocyte proliferation. Am J Clin Nutr 71, 950-955.

14. Wolvers DA, van Herpen-Broekmans WM, Logman MH, et al. (2006) Effect of a mixture of micronutrients, but not of bovine colostrum concentrate, on immune function parameters in healthy volunteers: a randomized placebocontrolled study. Nutr J 5, 28.

15. Stracke BA, Rüfer CE, Bub A, et al. (2009) Bioavailability and nutritional effects of carotenoids from organically and conventionally produced carrots in healthy men. $\mathrm{Br} J$ Nutr 101, 1664-1672.

16. Santos MS, Leka LS, Ribaya-Mercado JD, et al. (1997) Shortand long-term beta-carotene supplementation do not influence T cell-mediated immunity in healthy elderly persons. Am J Clin Nutr 66, 917-924.

17. Santos MS, Meydani SN, Leka L, et al. (1996) Natural killer cell activity in elderly men is enhanced by beta-carotene supplementation. Am J Clin Nutr 64, 772-777.

18. Santos MS, Gaziano JM, Leka LS, et al. (1998) Beta-caroteneinduced enhancement of natural killer cell activity in elderly men: an investigation of the role of cytokines. Am J Clin Nutr 68, 164-170.

19. Wood SM, Beckham C, Yosioka A, et al. (2000) Beta-carotene and selenium supplementation enhances immune response in aged humans. Integr Med 2, 85-92.

20. Walrand S, Moreau K, Caldefie F, et al. (2001) Specific and nonspecific immune responses to fasting and refeeding differ in healthy young adult and elderly persons. $A m J$ Clin Nutr 74, 670-678.

21. Watzl B, Bub A, Brandstetter BR, et al. (1999) Modulation of human T-lymphocyte functions by the consumption of carotenoid-rich vegetables. Br J Nutr 82, 383-389.

22. Hughes DA, Wright AJ, Finglas PM, et al. (2000) Effects of lycopene and lutein supplementation on the expression of functionally associated surface molecules on blood monocytes from healthy male nonsmokers. I Infect Dis 182, Suppl. 1, S11-S15.

23. Corridan BM, O’Donoghue M, Hughes DA, et al. (2001) Lowdose supplementation with lycopene or beta-carotene does not enhance cell-mediated immunity in healthy free-living elderly humans. Eur J Clin Nutr 55, 627-635.

24. Walrand S, Farges MC, Dehaese O, et al. (2005) In vivo and in vitro evidences that carotenoids could modulate the 
neutrophil respiratory burst during dietary manipulation. Eur J Nutr 44, 114-120.

25. Ligthart GJ, Corberand JX, Fournier C, et al. (1984) Admission criteria for immunogerontological studies in man: the SENIEUR protocol. Mech Ageing Dev 28, 47-55.

26. Olmedilla B, Granado F, Southon S, et al. (2002) A European multicentre, placebo-controlled supplementation study with alpha-tocopherol, carotene-rich palm oil, lutein or lycopene: analysis of serum responses. Clin Sci (Lond) 102, 447-456.

27. Lyan B, Azais-Braesco V, Cardinault N, et al. (2001) Simple method for clinical determination of 13 carotenoids in human plasma using an isocatric high-performance liquid chromatographic method. J Chromatogr B Biomed Sci Appl 751, 297-303.

28. Walrand S, Valeix S, Rodriguez C, et al. (2003) Flow cytometry study of polymorphonuclear neutrophil oxidative burst: a comparison of three fluorescent probes. Clin Chim Acta 331, 103-110.

29. Olmedilla B, Granado F, Southon S, et al. (2001) Serum concentrations of carotenoids and vitamins A, E and C in control subjects from five European countries. Br J Nutr 80, 227-238.

30. Burns EA (2004) Effects of aging on immune function. J Nutr Health Aging 8, 9-18.

31. Carson PJ, Nichol KL, O'Brien J, et al. (2000) Immune function and vaccine responses in healthy advanced elderly patients. Arch Intern Med 160, 2017-2024.

32. Paganelli R, Quinti I, Fagiolo U, et al. (1992) Changes in circulating B cells and immunoglobulin classes and subclasses in a healthy aged population. Clin Exp Immunol 90, $351-354$.

33. Ginaldi L, De Martinis M, D'Ostilio A, et al. (1999) The immune system in the elderly: I. Specific humoral immunity. Immunol Res 20, 101-108.

34. Lesourd BM \& Meaume S (1994) Cell mediated immunity changes in ageing, relative importance of cell subpopulation switches and of nutritional factors. Immunol Lett $\mathbf{4 0}$, $235-242$.

35. Minet-Quinard R, Farges MC, Thivat E, et al. (2010) Neutrophils are immune cells preferentially targeted by retinoic acid in elderly subjects. Immun Ageing 7, 10.

36. Mazari L \& Lesourd BM (1998) Nutritional influences on immune response in healthy aged persons. Mech Ageing Dev 104, 25-40.

37. Bendich A (1991) Beta-carotene and the immune response. Proc Nutr Soc 50, 263-274.

38. Collins AR (2001) Carotenoids and genomic stability. Mutat Res 475, 21-28.

39. Astley SB, Elliott RM, Archer DB, et al. (2004) Evidence that dietary supplementation with carotenoids and carotenoidrich foods modulates the DNA damage: repair balance in human lymphocytes. BrJ Nutr 91, 63-72.

40. Albers R, Antoine JM, Bourdet-Sicard R, et al. (2005) Markers to measure immunomodulation in human nutrition intervention studies. Br J Nutr 94, 452-481.

41. Azais-Braesco V, Winklhofer-Roob B, Ribalta J, et al. (2000) Vitamin A, vitamin $\mathrm{E}$ and carotenoid status and metabolism during ageing: functional and nutritional consequences. Endocr Regul 34, 97-98.

42. Mobarhan S, Bowen P, Andersen B, et al. (1990) Effects of $\beta$-carotene repletion on $\beta$-carotene absorption, lipid peroxidation, and neutrophil superoxide formation in young men. Nutr Cancer 14, 195-206.

43. Dixon ZR, Burri BJ, Clifford A, et al. (1994) Effects of a carotene-deficient diet on measures of oxidative susceptibility and superoxide dismutase activity in adult women. Free Radic Biol Med 17, 537-544.

44. Girodon F, Blache D, Monget AL, et al. (1997) Effect of two year supplementation with low doses of antioxidant vitamins and/or minerals in elderly subjects on levels of nutrients and antioxidant defense parameters. J Am Coll Nutr 16, 357-365. 